\title{
Az archaikus költészet szerepe Ioachimus Vadianus költészetelméletében
}

The aim of my study is the analysis of the views on the archaic Latin literature in the early modern works based on the theory and practice of poetry, especially in the Swiss humanist's, Joachim von Watt's work (De poetica et carminis ratione). The concepts of poeta vates, poeta theologus, and poeta eruditus are commonly used by the Italian authors - who knew the most important authors of the early Roman literature regarding this period - in order to emphasize the moralistic and social morals of the archaic poetry's lecture. Some of the authors - for example Pietro Crinito - following Suetonius emphasized the historical analysis of the ancient literature in a particular way. The innovation of Joachim von Watt's work was the adaptation of this view of the Italian authors, and it is not present in the works of other Viennese humanists on poetry in the first half of the $16^{\text {th }}$ century. ${ }^{1}$

A 16. századi humanisták felfogásában a poétikai ismeretek az antik és középkori gyakorlatot követve szintén a retorikaoktatás részét képezték. ${ }^{2}$ A reneszánsz irodalomelmélet legfontosabb antik forrásait Horatius Ars poeticája (és ennek késő antik kommentárjai), Arisztotelész Poétikája, illetve Platón dialógusai jelentették, azonban a fő források mellett a

\footnotetext{
${ }^{1}$ A publikáció az MTA-SZTE Antikvitás és Reneszánsz: Források és Recepció Kutatócsoport (TK2016-126) támogatásával jelent meg.

$2 \mathrm{Az}$ antik retorikai munkák két nagy csoportját a filozófiai-logikai színezetü arisztotelészi felfogás és a római joghoz közel álló, pragmatikus irányultságú cicerói retorika jelentik, azonban a preceptív szándék a két irányzat közös pontját jelenti (hasonlóan Horatius Ars poeticájához, amely a költészetre alkalmazza a retorika szabályrendszerét). A késő antikvitásban a társadalmi és politikai körülmények hatására az epideiktikus (demonstratív) szónoklat válik gyakorlattá, és a retorikai képzés meghatározó gyakorlati elemévé (amelynek a költészet is részét jelenti) a középkori illetve a kora újkori retorikaoktatásban is. MURPHY (1974: 4).
} 
poétikai munkák szerzői Cicero, Quintilianus, és Rutilius Lupus írásaira is támaszkodtak. ${ }^{3}$ A 16 . században egyrészt az antik munkákat adták ki poétikatankönyvként (számos esetben kommentárral ellátva) vagy a retorikát oktató humanisták maguk írtak önálló értekezéseket vagy dialógusokat. Annak köszönhetően, hogy a középkori és a kora újkori grammatika- és retorikaoktatásban jelentős szerepet töltöttek be, az archaikus kor szerzői közül csak a latin nyelvű komédiairodalom jelentős képviselőinek a müveit jelentették meg, illetve írtak hozzájuk kommentárokat, a kora újkori szerzők azonban az antik forrásokból ismerték Livius Andronicust és Enniust, mint az első latinul író költőket is. ${ }^{4}$

A korabeli munkákban nagy szerepe volt a költészet korabeli társadalmi megítélésének is: a szerzők a költővé koszorúzás gyakorlatára való utalásoktól kezdve a költészettel szemben megfogalmazott morális ellenérvek hangoztatásáig az egymással rokon vagy eltérő álláspontok széles skáláját vonultatják fel, amelyeknek az archaikus irodalomról alkotott képre is hatásuk volt. A humanista poétikák alapvető kérdéseit az archaikus költészetnek, illetve a költészet kezdeteinek tárgyalása esetében a poeta vates szerepe, illetve a poétikai tevékenység társadalmi és morális haszna jelentik, amely gondolati rendszer hátterében az arisztotelészi, platonikus, és horatiusi felfogás hatásai egyaránt megjelennek.

A 16. század első évtizedeiben megjelent poétikai munkáknak az archaikus latin irodalmat tárgyaló szakaszaiban szereplö, az archaikus költők morális és társadalmi szerepét hangsúlyozó szempontok hátterében az antikvitástól örökölt poeta theologus és poeta vates, illetve poeta eru-

\footnotetext{
3 Pign. Poet. Hor. 34: Et Cicero in Legibus elegorum nomine Ennii epitaphium quatuor versibus hexametris pentametrisque conscriptum adduxit.

${ }^{4}$ Polidoro Virgili az antik forrásokra alapozva tartja Livius Andronicust az első latin nyelven alkotó költőnek, azonban nem tekint rá isteni ihletettségű vatesként. A hozzá hasonlóan irodalomtörténeti megközelítést alkalmazó Pietro Crinito azt emeli ki, hogy Livius Andronicus foglalkozott elsőként a poétika elméleti tanulmányozásával, és a De bello Punico című eposz megírásával a célja eredményeinek a gyakorlati bemutatása volt. Crinito De poetis Latinis című munkája az egyes költők életrajzi adatait gyűjti össze. Ezeknek a jellemző módszertani elemeit a születési körülmények, a költő morális jellemzése, társadalmi kapcsolatainak bemutatása, műveinek és műfordításainak felsorolása (esetenként egy-egy idézettel), végül halálának körülményei, illetve recepciója jelentették. Ez a séma nem volt egységes, de az alapelemei Ennius esetében is felismerhetőek.
} 
ditus fogalmak együttes hatását tételezhetjük fel. A korabeli szerzők munkáiban gyakran találkozhatunk annak az elképzelésnek a különféle megfogalmazásaival, hogy a költészet kezdeteit és későbbi fejlődését elsősorban a vates, illetve theologus szerepet betöltő költők határozták meg. Albertino Mussato, Francesco Petrarca és több itáliai humanista kronológiai szempontból is foglalkozott az archaikus költészet történetével, azonban az elsődleges szempontot a költészet védelme során az archaikus vates-költők szerepének kiemelése jelentette számukra. A vates szerepét betöltő költők mellett a 15-16. századi poétikákban szerepelnek olyan archaikus költők is, akik mint poetae eruditi társadalmi szempontból jelentős üzeneteket közvetítettek. A poétikák az ő esetükben azt állították a középpontba, hogy milyen stilisztikai eszközök segítségével ábrázolják a koruk társadalmi valóságát és ennek során milyen morális tartalmakat jelenítenek meg. A két szerepkör nem minden szerzőnél válik el határozottan egymástól, azonban a poétikai munkák egy részének alapját jelentő irodalomtörténeti és stilisztikai elemzésben, amely az antik forrásokból megszerezhetö összes adat felhalmozásával a latin nyelvű költészet első képviselőire vonatkozóan is számos információt közölt, jóval hangsúlyosabban jelenik meg az archaikus költők poeta eruditus-szerepe. Ezt a módszertani gyakorlatot egyrészt az antikvitástól kezdve szerepet játszó és a kora újkorban is jelentős enciklopédizmus, másrészt a sallustiusi modell követése határozta meg.

A 16. század első felének egyes poétikai munkáiban nem voltak jellemzőek sem az egyik, sem a másik álláspont kizárólagos voltát hirdető elképzelések, és az archaikus költészettel kapcsolatos gondolkodást alapvetően befolyásolták a poétikaelméleti tevékenység számára adott korabeli keretek is: az egyetemi retorikaoktatás részét jelentő poétika teoretikus tanulmányozásának hátterét a költészettel szemben megfogalmazott érvekre adott válaszok jelentették, amelyek rendre megjelennek a kora újkori poétikáknak az archaikus irodalmat tárgyaló szakaszaiban is, különösen a költészet társadalmi és morális hasznával összefüggő érvek esetében. ${ }^{5}$ Az elméleti munkák szerzői általában nagy hangsúlyt fektetnek a költészet oktatásban betöltött szerepével kapcsolatos elutasító véleményekre adott ellenérvek kidolgozására, amelyben fontos

${ }^{5}$ BuCK-HEITMANN-METTMANN (1972: 13). 
szerepe van a költészet kezdeteinek, az első görög és latin nyelven író költők isteni ihletettségének. Az irodalomtörténeti szempontokat előtérbe állító, és a költészet társadalmi hasznát bizonyítani kívánó felfogás a költészetnek a retorikaoktatásban már kivívott szerepének megszilárdítására, és nem a védelmére törekedett. Itt az archaikus költők társadalmi szempontból jelentős személyekként jelennek meg, azonban a humanista szerzők nem vatesként említik őket, mivel a poétikák az ő esetükben azt hangsúlyozták, hogy milyen stilisztikai eszközök segítségével ábrázolják a koruk társadalmi valóságát, és ennek során milyen morális tartalmakat jelenítenek meg (a módszer alkalmazásának egyik jellemző példáját Pietro Crinito De poetis latinis címen megjelent munkája jelenti). A humanista poétikáknak ez a csoportja tisztában van a római irodalom kezdeteivel, a legfontosabb archaikus müfajokkal és szerzőkkel, és egyes esetekben a kronológiai határokat is meg tudják állapítani (Polidoro Virgili - Vergilius Polydorus - például felismeri a római irodalomnak a más ókori irodalmakhoz képest későbbi kezdeteit).

Az itáliai humanisták latin nyelvü poétikaelméleti munkái a görög és a római költészet kezdeteit, illetve az archaikus költészetet kétfajta módon értelmezték: egyes szerzők a kezdetekből kiinduló folyamatos fejlődést tételeztek fel, míg mások ezt az időszakot a hanyatlás és fejlödés periodikus változásaival jellemezték. Az archaikus költészet itáliai humanista értelmezésén belül az előbbiekben bemutatott, ókori retorikai és irodalmi modellekre épülő historiográfiai, illetve irodalomtörténeti szempontok jelenthetik a legfontosabb újítást. Ezek a szempontok nem szerepeltek sem Konrad Celtis, sem Frederic Nausea müvében, és a bécsi humanisták közül elsődlegesen Vadianus alkalmazta őket. ${ }^{6}$

\footnotetext{
${ }^{6}$ Konrad Celtis Ars versificatoria et carminum című munkája Horatius nyomdokain haladva elsődlegesen a metrikai, formai, és verstani szempontokat tartotta szem előtt. A bécsi püspök, Frederic Nausea 1522-ben megjelent In artem poeticen carminumque condendorum primordia című munkája például, bár egyes költőket, például Enniust megemlíti ugyan, azonban nem alkalmaz irodalomtörténeti korszakbeosztást, emellett pedig a poétikaértelmezésének középpontjában a poeta vates szerepének bemutatása áll.
} 


\section{$\mathrm{Az}$ archaikus görög és latin költészet a De poetica et carminis ra- tione szövegében ${ }^{7}$}

Vadianus ebben az évben megjelent másik munkájában, a Pomponius Mela földrajzi munkájához írt kommentárban az archaikus költőkre történő hivatkozások, illetve a tőlük vett idézetek nagyon alacsony arányban szerepelnek. A korabeli retorikai képzésben a szerepük elsődlegesen arra irányult, hogy valamilyen morális üzenetet vagy mitológiai tudnivalót közvetítsenek, és a kommentár esetében Vadianus is az antik és középkori hagyományoknak megfelelő gyakorlatot követi. Plautus esetében a Captiviből vett egyik idézet a fösvénység bünével kapcsolatban szerepel, ${ }^{8}$ Enniust pedig Lactantiuson keresztül idézi, amikor az általa készített latin nyelvű Euhémeros-fordításából átveszi a Iuppiterre vonatkozó mitológiai leírást. Ebben az esetben Ennius annak a racionalizáló felfogásnak a közvetítooje Vadianus számára, hogy a mitológiai történeteket emberi eredetűnek tekinthetjük, szemben az isteni kinyilatkoztatással (ebben az esetben tehát Ennius mint poeta eruditus és nem mint poeta vates szerepel). ${ }^{9}$

A De poetica et carminis ratione archaikus költészetre vonatkozó szakaszainak célja a görög, illetve latin nyelvű költészet kezdeteinek törté-

\footnotetext{
7 Vadianus múve 1973-ban a Peter SCHÄFFER által gondozott kritikai kiadásban jelent meg, amelyhez a szerkesztő kommentárt is írt. Ebben az archaikus irodalomról alkotott képpel kapcsolatban azt a tényt állapítja meg, hogy Vadianus az ókori költészet kezdeteit egységben szemlélte, és párhuzamba állította a héber, görög, latin és német költészet kezdeteit.

${ }^{8}$ Vad. Pomp. Mel. 54: Pestium. Nullum enim est sceleris genus ad quod auro argentove non impellamur: nec quicquam publicae saluti magis noxium, quam quae haec sitit avaritia. Unde perbelle Pythius a Lacedaemoniis interrogatus, qua re statum reipublicae amissuri essent? Avaricia respondit, ut Cicero scribit libro de Officiis secundo. Nec inelegans illud est ex Captivis Plauti Odi ego aurum, multa saepe multis persuasit perperam.

9 Vad. Pomp. Mel. 82: Ennius in sacra historia, Iupiter, inquit, postquam terram quinquies circuivit, omnibusque amicis et cognatis suis imperium divisit, reliquitque hominibus leges, mores, frumentaque paravit, multaque alia bona fecit, immortali gloria memoriaque affectus, sempiterna monimenta suis reliquit: aetate pessumata in Creta vitam commutauit, et ad Deos abiit: eumque Curetes filii sui curaverunt decoraveruntque, et sepulchrum eius in Creta est oppido Gnoso: et dicitur Vesta hanc urbem creavisse, in qua sepulchro eius est inscriptum antiquis literis graecis... Scribit haec Lactantius capite undecimo libri divinarum institutionum primi.
} 
neti kontextusba illesztett rendszerezett tárgyalása volt, amely a költészet hasznára vonatkozó értekezéseket, valamint a verstani témájú fejezeteket alapozta meg. Az archaikus költészet jelentőségét mutatja, hogy a mü két fejezetre osztva tárgyalja a latin nyelvü irodalom történetét, és egy teljes fejezetet szentel a kezdetektől Vergiliusig tartó időszaknak, és még egy fejezetet szentel annak a kérdésnek, hogy az első költőket teológusoknak kell tekinteni. Az archaikus költészet tárgyalására vonatkozóan Vadianus munkáját az itáliai humanista poétikaelméleti megközelítések egymással összekapcsolódva határozzák meg: a De poetica et carminis ratione a poeta theologus és poeta vates, illetve a poeta eruditus elképzelését együtt alkalmazva, az irodalomtörténeti szempontokra alapozva tárgyalja (például Vergiliusra támaszkodva Enniust is a vatesköltők közé sorolja, de életrajzi adatokat is közöl vele kapcsolatban, és a római történelem kontextusába állítja a személyét). Az irodalom kezdeteivel és az archaikus római költészettel kapcsolatos megállapítások a 2. és 5. fejezetben (De origine poetices; Qui vetustissimi apud Latinos poetae et inibi de Ennii et Maronis laudibus), továbbá a 8. fejezetben (De multiplici genere poetarum et variis poematum speciebus) szerepelnek. A 2. fejezet kiindulópontját a költészet eredetével, illetve fejlődésével kapcsolatban a folyamatos fejlődést feltételező elképzelés jelenti, amely az archaikus költészet szerény, de alapot teremtő szerepét hangsúlyozza. ${ }^{10}$ Ezt a fej-

\footnotetext{
${ }^{10}$ A 15-16. századi szerzők fokozatosan formálódó felismerését, amely Vadianusnál is megjelenik, a 16. század végén megjelent poétikák szerzői egyrészt átvették, másrészt új szempontokkal gazdagították. Giovanni Antonio Viperano De arte poetica libri tres (1579) című munkájának az archaikus költészetet tárgyaló szakaszai szintén a folyamatos fejlődést feltételező irodalomtörténeti-historiográfiai felfogást követik. A De origine et laudibus poeticae címet viselő második fejezet együtt tárgyalja a görög és a latin költészet kezdeteit, amelyekkel kapcsolatban sokkal több és rendszerezettebb adatot közöl, mint a 16. század elején müködő elődei. A költészet eredetét mitológiai, történelmi, és földrajzi szempontból jóval szélesebb léptékben tárgyalja, azonban közös vonást jelent a korábbi munkákkal, hogy az előbbi szempontokat összekapcsolja egymással, és a költészet eredetével kapcsolatban megjegyzi, hogy az első emlékei a trákok körében születtek meg. Antik alapjait tekintve a fejezet eklektikus képet mutat: bár abból az arisztotelészi elképzelésből indul ki, hogy a költészet eredete az utánzásra való képesség, amellyel kapcsolatban megállapítja, hogy ez Istentől ered (vagyis lényegében a poeta theologus elképzelését fogadja el). Innen már csak egy lépés az isteni ihletettségű poeta vates platonikus elképzelése, és a szerző éppen ebbe az irányba
} 
lődést lassú folyamatnak látja, amelynek a kezdeti időszakban nem voltak jelentős eredményei, emellett hangsúlyozza azt a patrisztikus irodalomtól kezdve jelenlevő gondolatot, hogy a költészet kezdetei az ószövetségi költészethez (Hebraica veritas) nyúlnak vissza. ${ }^{11}$ Ezt az érvet használja fel annak a bizonyítására, hogy az archaikus költészet lényegi részét jelenti az ókori irodalmak (így a római irodalom) fejlődéstörténetének is, továbbá a legősibb szent nyelven írt költészethez hasonlóan a latin nyelvü költészetnek is az ősi volta jelenti az értékét, és mindez közvetlenül kapcsolódik a platonikus vates-fogalomhoz. Az 5. fejezetben a latin nyelvü költészet kezdetei, a vetustissimi poetae bemutatása során Ennius és Vergilius kapnak kiemelt szerepet. Emellett más humanista szerzőkhöz hasonlóan ő is osztja azt a véleményt, hogy Livius Andronicus volt az első latin nyelven író költő, azonban beszámol az őt megelőző nyelvemlékekről is. A római költészet ősi volta Vadianus értelmezésében azt jelenti, hogy a kezdetei nem hirtelen, villámcsapásszerü jelenségként (mint az ingenium megnyilvánulása) jelentek meg, hanem már az ősi időkben is léteztek a vallási szertartások során használt énekek. Ezeket carmen decantatorium néven említi, és az antik forrásokból ismeri a carmen Saliare müfaját is. Ezeket és egyéb müfajokat (például a lakomákon zenei kísérettel előadott, a nagy emberek tetteiről szóló énekeket) az archaikus eposz előzményének, a hozzá vezető köztes állomásnak tekinti. A 8. fejezetben az irodalmi müfajok között ötödikként tárgyalja az archaikus komédia müfaját, amelynek a bemutatásakor a képviselőit a poetae eruditi körébe sorolva a drámai müfajokat általában a társadalmi szempontból hasznos, erkölcsi tanulságot közvetítő müfajok

halad tovább, és ennek a jelenségnek tulajdonítja a költészet folytonos, lineáris fejlődését. Vö. Vip. Poet. 11-15.

${ }^{11}$ A gondolat más korabeli szerzők poétikai munkáiban is szerepel, akik közül néhányan közlik is ennek az elképzelésnek a forrását. Polidoro Virgili (Polydorus Vergilius) például a költészet ősi eredetével kapcsolatban Eusebiusra hivatkozik, aki szerint Mózes volt az első, aki isteni (a Szentlélek által ihletett) vatesként nyilvánult meg, majd az ókori egyházatya általa feltételezett forrását, Josephus Flaviust is idézi erre a kérdésre vonatkozóan. Ld. Pol. Verg. de Inv. 30. 
között tünteti fel, itt tehát az archaikus komédiairodalom hagyományos értelmezését követi. ${ }^{12}$

$\mathrm{Az}$ archaikus költészetre vonatkozó ismeretek tárgyalása során a forráskezelési módszereket Vadianus más müveihez hasonlóan a sokszínúség jellemzi: a magas arányban hivatkozott Cicero és Quintilianus mellett több antik költő, történetíró, illetve patrisztikus szerző szerepel forrásként. A források sokszínüsége és az általuk közölt anekdoták Vadianus munkáját Antonio Mancinelli itáliai humanista poétikaelméleti múvével állítják párhuzamba. ${ }^{13} \mathrm{Az}$ ókori forrásoktól eltérően a korábbi vagy kortárs humanistákat nem nevezi meg név szerint, ugyanakkor valószínünek tekinthető, hogy Vadianus olyan irodalomtörténeti munkákhoz is hozzáférhetett Bécsben, amelyek foglalkoztak a korai latin nyelvű irodalom belső fejlődésével is, és ezeknek a müveknek az ismeretében tudta rendszerezni az általa olvasott antik forrásokban szereplő ismereteket. ${ }^{14}$ Ennek kapcsán felmerül a kérdés, hogy használhatott-e

\footnotetext{
12 Vad. Poet. et Car. 59: Comoedia speciei quintae civilis fortunae materiam sine vitae periculo complectitur, a quo comici poetae et comoediae histriones. Donatus ait comoediam esse fabulam continentem affectum civilium ac privatorum qua discitur quid sit in vita utile quid contra evitandum, quam Cicero eodem autore dixit imitationem esse vitae speculum consuetudinis et imaginem veritatis.

${ }^{13}$ Antonio Mancinelli Opusculum perelegans de virtute poetica címú munkája ajánlólevelének záró szakaszában szerepel az a megjegyzés, amely a költészet kezdeteit a görög történelem kezdeteinek kontextusába helyezi. Mindez már előrevetíti a magában a müben szereplő irodalomtörténeti szempontokat, amelyeket Mancinelli a mü első fejezetében a korabeli gyakorlatnak megfelelően az ókori auctoroktól vett anekdoták formájában dolgoz fel, epizódszerüen felvillantva a költészet kezdeteinek és fejlődésének egyes, meghatározott szerzőkhöz köthető állomásait. Mindezek csak a bevezetőjét jelentik a Quintilianustól kölcsönzött végső megállapításnak, amelynek a célja az archaikus szövegek retorikai felhasználásával kapcsolatos tanácsok közlése. Itt az archaikus költők, illetve múveik mint morális exemplumok érdekesek, és az irodalomtörténetinek tekinthető szempontok a retorikaoktatás gyakorlati követelményeinek vannak alárendelve. Vö. Manc. de Virt. Poet. 5.

14 A De poetis latinis ismeretének és alkalmazásának további bizonyítékát jelenti az 1515-ben Bécsben megjelent Persius-kiadás, amelyben a szerző életrajzát a kötet kiadója Crinitótól vette (Vita Persii ex libro tertio Criniti de poetis latinis). Bár a szerkesztőre vonatkozóan magában a kötetben nem szerepelnek további adatok, felmerül a kérdés, hogy Vadianus is dolgozhatott-e a kiadás előkészítésén. Ld. Pers. Sat. 6.
} 
kortárs humanista forrásokat, például a De poetis latinist. ${ }^{15}$ A Melakommentár hivatkozásai alapján biztosnak tekinthetjük, hogy Vadianus ismerte Crinitusnak legalább egy munkáját, azonban valószínű, hogy ez a De honesta disciplina címmel kiadott commonplace-gyüjtemény lehetett, és nem az előbb említett poétikaelméleti munka. Bár a De poetis latinis és a De poetica et carminis ratione archaikus latin irodalmat tárgyaló szakaszai között vannak párhuzamok, inkább arról lehet szó, hogy Vadianus itt alkalmazta ugyan az itáliai humanista által használt irodalomtörténeti megközelítést, azonban azt jelentősen módosította a saját munkájában, amikor az ingenium-ars problémakört alkalmazva az archaikus költészet esetében a két nézőpont egymással való kiegyensúlyozására törekedett.

A De poetis latinis elsődleges forrásként történő felhasználását megcáfoló további érvet jelent, hogy a De poetica et carminis ratione alapelve az irodalomtörténetnek a római történelem keretei között történő tárgyalása volt, amelyet nemcsak Pietro Crinito, hanem más szerzők is al-

15 Pietro Crinito szintén a lineáris fejlődést tartja szem előtt, ugyanakkor a mű fókuszában csak a latin nyelven író szerzők szerepelnek. A mühöz írt ajánlólevélben Crinito hangsúlyozza, hogy a költészet kezdeteinek, illetve történetének tárgyalása során a historiográfiai szempontokat részesíti előnyben, és a célját az jelenti, hogy a római történelemnek ezt az aspektusát bemutassa az olvasó számára. A római költészet legkorábbi emlékeinek bemutatását követően a De poetis latinis a költők (poetae eruditi) egymás után sorakozó életrajzaiból áll. Ezeknek a közlése során Crinito az archaikus irodalom esetében is a korszak teljes körü bemutatására törekszik, és ennek során számos antik forrásból vett idézetet és hivatkozást kapcsol össze egymással enciklopédikushoz hasonló tudásanyagot létrehozva. Az antik forrásoknak kiemelt jelentősége volt az archaikus költészet bemutatása során, amelynek az esetében kevés eredeti szöveg maradt az utókorra, és így számos szerző esetében csak az életrajzi adatok közlése segítségével lehetett a római költészet kezdeteiről képet alkotni. A római költészet legkorábbi emlékeivel, például a carmen Saliarével kapcsolatban Horatius jelenti számára a feltétlen tekintélyt, amikor átveszi azt az állítását, amely szerint a Numa Pompilius uralkodása alatti időszakból maradtak fel vele kapcsolatban az első tudósítások. Ennek az elképzelésnek a tévesként felismert voltára a 16. század végén megjelent munkák már felhívják a figyelmet: Nam cum Horatius, homo doctissimus, carmen Saliare Numa Pompilio regnante compositum fateatur ingenue se non intelligere, quomodo Brutus iste tot annos ante Salios institutos mortuus potuit intelligere carmina diu post Horatium, ut orationis tenor indicat, facta? Vö. Buch. Scot. 44. 
kalmaztak Itálián kívül is. ${ }^{16}$ Vadianus az archaikus irodalmat mint az infantia korát határozza meg a római irodalom történetének egészét tekintve, ami az emberi élet szakaszai és a historiográfiai korszakok közötti, a patrisztikus irodalomból a humanista szerzők által gyakran átvett párhuzam hatására utal, és nem a De poetis latinis közvetlen, a De poetica et carminis ratione módszertani felfogását megalapozó hatására. ${ }^{17}$ $\mathrm{Az}$ archaikus költészet kezdeteinek kronologikus és belső fejlődést feltételező felfogásának hátterében az irodalomtörténeti szempontokat előtérbe állító módszertani gyakorlat jelenik meg, amelyet korábban már több itáliai humanista szerző esetében is megfigyelhettünk. Vadianus esetében a római őstörténet iránti, a 16. század eleji humanistákra jellemző érdeklődés határozza meg az archaikus irodalom jelentőségét, és ez kapcsolódik össze nála az irodalomtörténeti felfogással és a poeta vates-fogalom hatásával.

\footnotetext{
16 Albrecht von Eyb szabályokra (praecepta) épülő munkája, a Margarita poetica a retorikai és ennek részeként a poétikai tevékenység gyakorlati müveléséhez adott tanácsokat. A retorikai szabályokat, a ritmikus mondatvégeket, illetve az antik szerzők (auctoritates) műveiből összeállított idézetgyűjteményt tartalmazó kötet utolsó szakaszában szerepelnek nagyobb arányban az archaikus kor költőire történő hivatkozások is, a mü céljának megfelelően gyakorlati szempontokat követve. A vir prudentissimus jelzővel ellátott Enniusra például von Eyb három alkalommal hivatkozik, két alkalommal moralizáló szándékkal, egy másik esetben a költészet platonikus értelmezését alátámasztandó, ezzel szemben Plautus és Terentius esetében életrajzi adatok is szerepelnek a müveikből vett külön fejezetekként szereplő idézetek mellett, azonban itt a rendezőelvet nem a kronológiai sorrend jelenti. A Margarita poeticában a hagyományos retorikai gyakorlatnak megfelelő moralizálás, illetve az auctoritas szerepének középpontba állítása figyelhető meg az archaikus költészetre vonatkozóan, másrészt a költőéletrajzokon keresztül már megjelennek a retorikai képzés részeként ennek az időszaknak az irodalomtörténeti kontextusba való állítására utaló első jelek is. Ennek a hátterében - a Margarita poetica esetében - szintén a moralizáló törekvés állhatott: ahogy van Eyb a tartalomjegyzékben utal rá, a mü anyagának összeállítása során az egyik szempont a helyes életvitel (recta vivendi forma) kialakításának támogatása volt, és az antik költőéletrajzok és a bennük szereplő morális tartalmak is ehhez nyújthattak segítséget a szerző szándéka szerint.

17 A 16. század második felében Giovanni Battista Pigna szintén ezt az elképzelést fogalmazza meg, és a forrását is megjelöli, Eusebius Chroniconját. Az infantia fogalmához kapcsolódik az a megállapítása is, hogy a latin költészet görög eredetének tényét emeli ki, azonban értékként kezeli a római költők esetében a szorgos utánzást, és a görögöktől átvett ismeretek és módszerek kitartó használatát.
} 


\section{Összegzés}

A De poetica et carminis ratione archaikus irodalomról alkotott képe sok szempontból az antik és korabeli poétikai elképzelések hatását mutatja, azonban ezeket egyéni szempontokat is követve valósítja meg. Alapvető különbséget jelent, hogy a korábbi német szerzőktől (Ulrich von Hutten, Konrad Celtis) eltérően prózai művet írt, és ebben az irodalomtörténeti elemzés részét jelenti az archaikus költészet tárgyalása is (amelynek a hátterében a költészet társadalmi és oktatási szerepének megszilárdítását célzó szándék állhat). A görög és a római költészet kezdeteinek külön fejezetben való tárgyalása által Vadianus azt a megállapítását hangsúlyozza, hogy bár a római költészet modellje a görög volt, az első irodalmi emlékeket mégsem lehet pusztán utánzásnak tekinteni. Nincsenek arra vonatkozóan biztos adatok, hogy Livius Andronicus és Ennius, illetve az archaikus latin nyelvü költészet emlékei szerepeltek-e a mü alapját jelentő retorikai órákon (amennyiben igen, ez további jelentős újítást jelent a bécsi egyetemi oktatásban). Az archaikus költészeti emlékek tárgyalásának másik fontos szempontja szintén a retorikai képzéshez kapcsolódik: Vadianus a kezdeti latin nyelvü költészet legfontosabb sajátosságának az archaikus szókincset tartja, és úgy véli, hogy ezek a munkák nem önmagukban fontosak, hanem a korábbi nyelvállapot rögzítése miatt. Mindezek alapján a további kutatás célja annak a vizsgálata lehet, hogy a retorikaoktatás követelményei mennyiben határozták meg a De poetica et carminis ratione költészetről alkotott felfogását.

\section{Források}

Buch. Scot.

Rerum scoticarum historia auctore Georgio Buchanano Scoto, Francofurti, 1583.

Crin. de Poet. $\quad$ Petri Criniti libri de poetis latinis, Florentiae, 1505.

Manc. de Virt. Poet. Opusculum perelegans facundi vatis Antonii Mancinelli de virtute poetica vocitatum, Deventer, 1504.

Pers. Sat. $\quad$ A. Flacci Persii satyrarum opus, Viennae Pannoniae, 1515.

Pign. Poet. Hor. Ioanni Baptistae Pignae poetica horatiana, Venetiis, 1561.

Vad. Poet. et Car. Ioachimi Vadiani Helvetii de poetica et carminis ratione liber ad Melchiorem Vadianum fratrem, Viennae, 1518.

Vad. Pomp. Mel. Pomponii Melae Hispani libri de situ orbis tres adiectis Ioachimi Vadiani Helvetii in eosdem scholiis addita quoque in geographiam catechesi, et 
epistola Vadiani ad Agricolam digna lectu, Viennae Pannoniae, 1518.

Pol. Verg. de Inv. Polydori Vergilii Urbinatis de inventoribus rerum libri tres, Argentoraci, 1509.

Vip. Poet. Ioanni Antonii Viperani de poetica libri tres, Antverpiae, 1579.

\section{Felhasznált irodalom}

BUCK-HEITMANN-METTMANN 1972

A. BuCK - K. HeITMANN - W. MetTMAnN (eds.), Dichtungslehren der Romania aus der Zeit der Renaissance und des Barock, Frankfurt am Main, 1972.

MURPHY 1974

J. MuRPHY, Rhetoric in the Middle Ages, Berkeley-Los AngelesLondon, 1974. 